PART ONE

Culture of Maqam 



\section{Musical Empires}

The longest-standing basic principles of music's structure in the documented history of the Persian-speaking world emerged and thrived within the context of dynastic rule that succeeded the waning Islamic Caliphate. With Islam underpinning the rise of Mongol and Turkic kingdoms in the thirteenth century, different versions of the same basic concept of the twelve-maqam system appeared on opposite sides of the Caliphate's domain in West and Central Asia. It then moved from court to court as musicians and their music adapted to the changing fortunes of dynastic patrons and the rise and fall of empires. In this context, documentation surrounding this approach to music comes from the various cities where dynastic rulers and their aristocracies resided at any given time, cities as far east as Bukhara and as far west as Baghdad. Documentation of the twelve-maqam system eventually also appeared in South Asia and Anatolia as rulers who patronized the system moved to occupy more territory.

The twelve-maqam system thus embodied a basic concept of music-making for a polyglot cosmopolitan dynastic context over a wide geographic and linguistic area. Yet it also mostly occupied a narrowly defined cultural context: specific urban centers that stood as islands of dynastic rule. The association of the twelvemaqam system with a system of patronage emanating from dynastic courts placed it in a political space that typically stood separate from the larger geographies dynasts sought to control. This relationship between the twelve-maqam system and empire lasted throughout an era of dynastic governance, where an Arabized form of Persian functioned as the lingua franca of cosmopolitan empires where Islam continued to be the dominant religion that also sanctioned dynastic rule.

In current narratives of Iranian music history, the existence of the twelvemaqam system begins at the end of the 'Abbasid Caliphate's fall, between the twelfth and thirteenth centuries. It thrived through a perceived golden age of Ira- 
nian culture overseen by Mongol and Turkic rulers, peaked in the Timurid Empire in the fifteenth century, and entered a period of musical decline in the Safavid Empire of the sixteenth and seventeenth centuries. Both dynastic governance and the twelve-maqam system disappeared for good with the rise of the nation-state under Qajar rule in the nineteenth century.

The complex of ideas about music's structure and execution associated with the rubric of the twelve-maqam system stood for at least six centuries as a central embodiment of music's ideal organization and performance. At the core of this ideal was the idea of melodic organization being center in twelve primary pitch modalities. These pitch modalities - their relationships with additional derivative modalities and their application vis-à-vis rhythm in the course of composition-formed the basic conception of music's construction and creation. The details of modal derivation and compositional forms would change, and different rhythms would also appear at different times in this period, yet the structural logic expressed in the twelve-maqam system itself and the conception of its application in practice remained in place in various guises for six hundred years.

Documentation of the twelve-maqam system began in Arabic from the 'Abbasid capital Baghdad and in Persian from the Ghaznavid kingdom, one of the first Turkic Persianate kingdoms to overtake the Caliphate farther east in Central Asia. Writing for the 'Abbasid Caliph al-Musta'sim (r. 1242-1258), Safi al-Din Urmawi (d. 1294) initially produced the most widely cited Arabic texts that described a fundamental premise for pitch structures concordant with a basic model of the twelve-maqam system. His description came in the context of extrapolations on ideas about music found in the Greek-based tradition of Islamic philosophy that had previously developed within the Caliphate. While Safi al-Din's ideas would be remembered and quoted for centuries after his death, a man named Muhammad bin Muhammad bin Muhammad Nishaburi who served in the Turkic Ghaznavid court of Bahram Shah (r. 1118-1152) had written about a similar if simpler conception of twelve pitch modalities somewhat earlier. ${ }^{1}$ Nishaburi did not appear to know about the Graeco-Arabic writing tradition farther west, yet his structural conception of twelve primary pitch modalities mirrored Safi al-Din's discussions of twelve pitch modalities in significant ways.

Persian writings about music did eventually take on the influence of the Graeco-Arabic writing tradition, and many Persian writings that describe the twelve-maqam system in more consistent detail beginning in the fourteenth century reflect the influence of the broader philosophical discussions that had grown out of the prior Graeco-Arabic discourses on music. Some Persian writings comment directly on the writings of Safi al-Din, including writings about music from the mystical philosopher Qutb al-Din Shirazi (d. 1311), and the prolific court musician 'abd al-Qader al-Maraghi (d. 1434). Safi al-Din, Qutb al-Din, and Maraghi form the core of what Henry George Farmer called "the Systematic School" because of their ability to synthetize many of the priorities of earlier Graeco-Ara- 
bic writings in relation to practice. ${ }^{2}$ Yet all three also described some version of the twelve-maqam system, with Shirazi and Maraghi discussing it both as Safi al-Din described it and as an aspect of musical practice in their different lifetimes and locations. The relevance of themes derived directly from earlier Graeco-Arabic writings continued in the sixteenth century, as information from this earlier tradition transferred directly into subsequent Persian writings. Maraghi’s Persian writings were some of the most directly cited authorities on music in the fifteenth and sixteenth centuries, and writings like his kept the Graeco-Arabic framing of the twelve-maqam system represented by Safi al-Din. The longer that Persian remained the lingua franca, however, the more direct knowledge of the GraecoArabic tradition waned. By the seventeenth century, writings about the twelvemaqam system focused more completely on the twelve-maqam system, and had fewer philosophical trappings of earlier musical discourses. Basic themes initiated in Graeco-Arabic writing centuries earlier remained part of the musical discourse, but direct knowledge of the origins of these discourses dissipated.

\section{THE TWELVE-MAQAM SYSTEM: \\ CONSONANCE AND DERIVATION}

At its core, the twelve-maqam system was based on twelve abstract modalities that related to a larger concern with creating and organizing consonant sets of pitches that could be used for the purposes of music-making, once combined with separate concepts of meter and musical form. The few sources that actually outline parameters for these modalities represent them as octave scales. Thus Safi al-Din Urmawi referenced twelve modalities he called shadd and he presented each shadd as an eight-note scale with the first note representing the scale's last note a register lower. Safi al-Din placed these shadd into a theoretical schema for scale creation that Safi al-Din referred to as adwar (adwār). In this theoretical adwar, Safi alDin defined seven possible consonant tetrachords and twelve possible consonant pentachords that could combine to create different scale possibilities. The shadd represented twelve scales located at various placed in the adwar. The full adwar presented eighty-four possible distinct individual scales (dä'irah), and while each scale had a set numbered position in the totality of the scales ( $a d w \bar{a} r)$ the twelve shadd were each labeled with a distinct proper name: Oshshaq ('oshshāq), Nawa (nawā), Busalik (būsalīk), Husayni (hūsaynī), Hijaz (hijāz), Rahavi (rāhawī), Iraq ('irāq), Rast (rāst), Zangulah (zankūlah), Zir-Afkand (zīrāfkand), Bozork (bozork), and Isfahan (isfahān). Safi al-Din further provided charts showing the possible transpositions of these specific scales, independent of the logic of his adwar. ${ }^{3}$

Beyond these twelve shadd, Safi al-Din further designated six other named scales as avaz (awāzah): Gardaniya (kardāniya), Gawasht (kawāsht), Nawruz (nawrūz), Maya (māyah), Shahnaz (shahnāz), and Salmak (salmak). The musicologist Owen Wright has noted that while the shadd had a consistent octave 
organization that fit well within Safi al-Din's adwar, the avaz represented a mixture of modal possibilities, some that were structurally similar to the tetrachord/pentachord structure represented in the shadd and others that represented smaller sets of pitches. ${ }^{4}$ What distinguished both the shadd and the avaz from the rest of the scales in the adwar, however, was their apparent relation to practice. While Safi al-Din forwarded a seminal theory of scale creation that united concerns of theory with the realities of practice, the shadd and avaz were established aspects of practice, for which his theory of adwar could only partially account.

The unique phenomenon of the adwar notwithstanding, Safi al-Din wrote about two core features that would ultimately define the parameters of the twelvemaqam system over centuries. First was the notion of two distinct categories of twelve primary and six secondary pitch modalities that maintained meaningful associations with each other. Second was the notion that functional pitch modalities should derive from previously established consonant organizations of pitch. While Safi al-Din's specific use of pentachords and tetrachords would only ring true in certain places for a short period of time, the centrality of systematic modal derivation from previously established modal material within closed parameters lasted for the duration of the system's relevancy and defined its premise for legitimate consonant mode creation.

These two phenomena manifested in a different presentation in the writings of Nishaburi, who described twelve primary pitch modalities he called pardeh and six secondary modalities he called sho'beh (sho'beh). The terminology in his scheme was different than Safi al-Din's, and his description was less technical. He also wrote in generalities without outlining any specific scales. Yet Nishaburi highlighted the systematic derivation concept by emphasizing that the six secondary modalities derived from specific pairings of the twelve primary pitch modalities: each pardeh could be paired with another specific pardeh, and between the two a new modality was created, one of six sho ${ }^{\circ}$ beh total. ${ }^{5}$

The writings of Nishaburi and Safi al-Din read very differently and suggest various ways of thinking about how one type of modal entity would be derived from another. Orientalists and musicologists came to regard Safi al-Din's full adwar as a seminal creation in the history of music in the Middle East, because it combined the best features of the previously discussed theory of consonant scale creation with practical considerations of intervals on stringed instruments. Safi al-Din was one of the first writers on music in the Middle East to describe a system of scales that could be both systematic and used in practice. Graeco-Arabic writings produced by Islamic philosophers such as al-Farabi (d. c. 951) and Ibn Sina (d. 1037) were concerned about systemization of consonant pitch organization but did not attempt to integrate the Greek-based premise of their reasoning regarding pitch with practices of their time and place. Safi al-Din's adwar appeared to overcome this separation between philosophical principle and practice. He described two distinct categories of twelve- and six-pitch modalities in the context of many pos- 
sibilities for scales, which balanced concerns about systematic consonance with what would be functional in practice. ${ }^{6}$

Nishaburi, by contrast, did not write in conversation with previously established norms of the Caliphate's Graeco-Arabic writing tradition for music. Yet he still described two distinct sets of twelve and six pitch modalities, and located a systematic pattern of derivation, this time between the two categories of modalities. As writing about two distinct categories of pitch modalities continued past the final years of the Caliphate, a more consistent and specific conception of the twelve-maqam system emerged that in many ways reflected influence from both the concept outlined by Nishaburi and that of Safi al-Din.

It was in the fourteenth and fifteenth centuries that the term maqam became more consistently synonymous with the twelve primary modalities of the system, even as avaz became the consistent term for the six modalities that derived from the maqam. The term sho'beh came to denote pitch sets from which the maqam were derived. In principle, the idea of sho'beh could reference the basic premise of the pentachords and tetrachords Safi al-Din had conceived. But these sho'beh all had proper names and distinct modal identities and it is not apparent how many pitches constituted a sho 'beh. They could serve as the basis for a maqam or independent modal structures unto themselves, just like a maqam or avaz. Texts typically named twenty-four specific sho'beh and often showed pairs of specific sho'beh as being the basis for each of the twelve maqam, which were further mapped out in pairs to create the six avaz.

Like the avaz, it is not clear what the structural relationship was between specific maqam and their pairs of sho'beh. The few descriptions of the pitches of different sho'beh give varying numbers, anywhere from four to eight. Yet their presence was consistently explained using the idea they had a structural relationship with the twelve maqam, which in turn had a structural relationship with the six avaz. Texts about the twelve-maqam system debated other possibilities for constructing the twelve maqam and extrapolating additional modalities from them, but it was the relationship between the twelve maqam, six avaz, and twenty-four sho ${ }^{\circ}$ beh that ultimately stood as the prevailing core structure of mode creation.

This notion of a closed system of combining different consonant sets of pitches to create different pitch modalities had a further extrapolation beginning in the seventeenth century. While the avaz, maqam, and sho'beh remained, the sho'beh were further deconstructed into even smaller set of pitches typically referred to as gusheh. The gusheh was the least-described aspect of the twelve-maqam system. Some descriptions followed the pairing principle of the initial system's conception, with two gusheh forming each of the sho'beh for a total of forty-eight gusheh, while others described larger or fewer numbers of gusheh without explaining how these very small sets of pitches created each of the sho'beh. Yet the gusheh were considered the source of the sho'beh and thus stood as an extension of the basic notion of closed derivative pitch organization present in the twelve-maqam system from its earliest descriptions. 


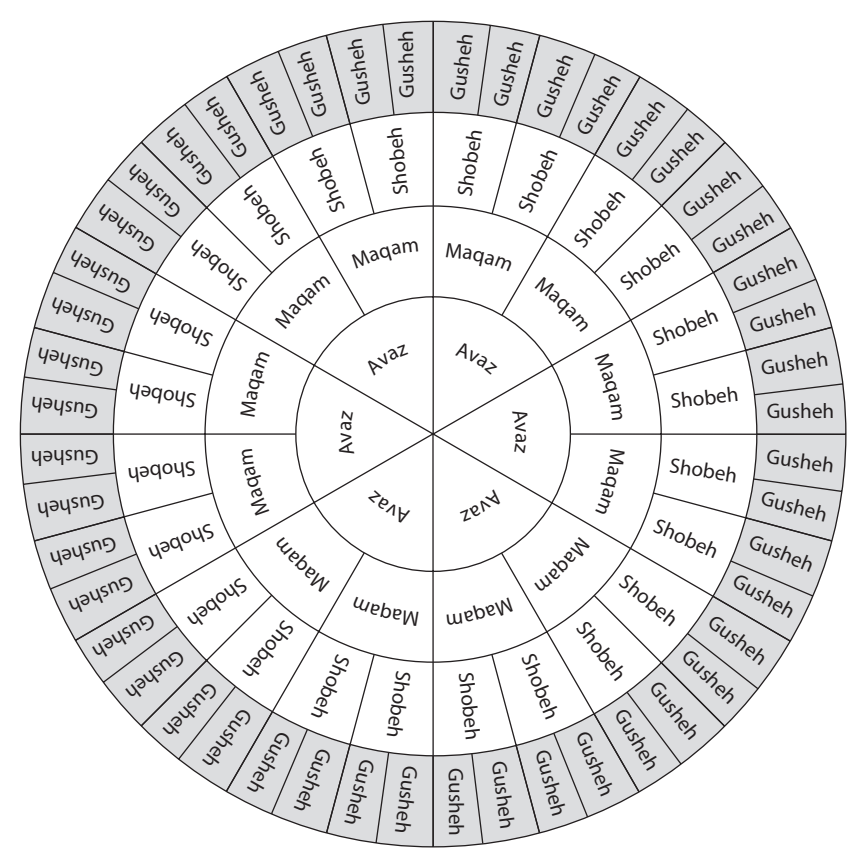

FIGURE 1. Common format for representing the twelve-maqam system as a closed, interconnected system

Owen Wright was the first modern musicologist to extrapolate notated scales for the twelve-maqam system, focusing on the handful of texts that actually name pitches associated with each maqam relatively early in the system's existence. Conversely, writings about the twelve-maqam system overall only occasionally dwelt on the specifics of pitch, focusing instead on the interrelationship of avaz, maqam, sho beh, and later the gusheh. In this context, the most common representation of the system was some kind of diagram that demonstrated the relationships between different aspects of the pitch organization. One of these representations was a circle, which mapped out the six avaz at the center, and twelve maqam around their parameter, naming which two maqam were used to derive each of the six avaz. A further rung mapped out which two sho ${ }^{\circ}$ beh formed each of the twelve maqam. Later depictions added gusheh around the sho'beh, naming each of the two gusheh that created each sho'beh (see figures 1 and 2).

By the fifteenth century, texts about music consistently emphasized the importance of interrelationship between aspects of the twelve-maqam system. The avaz could not exist without the maqam, and the maqam could not exist without the sho ${ }^{\circ}$ beh, and eventually the sho beh could not exist without the gusheh. The theoretical derivative interrelationships were central to the acceptance of the modalities as applicable in practice. Safi al-Din's full adwar of scale possibilities would never become relevant to ongoing music in practice: it was the interrelated modal- 


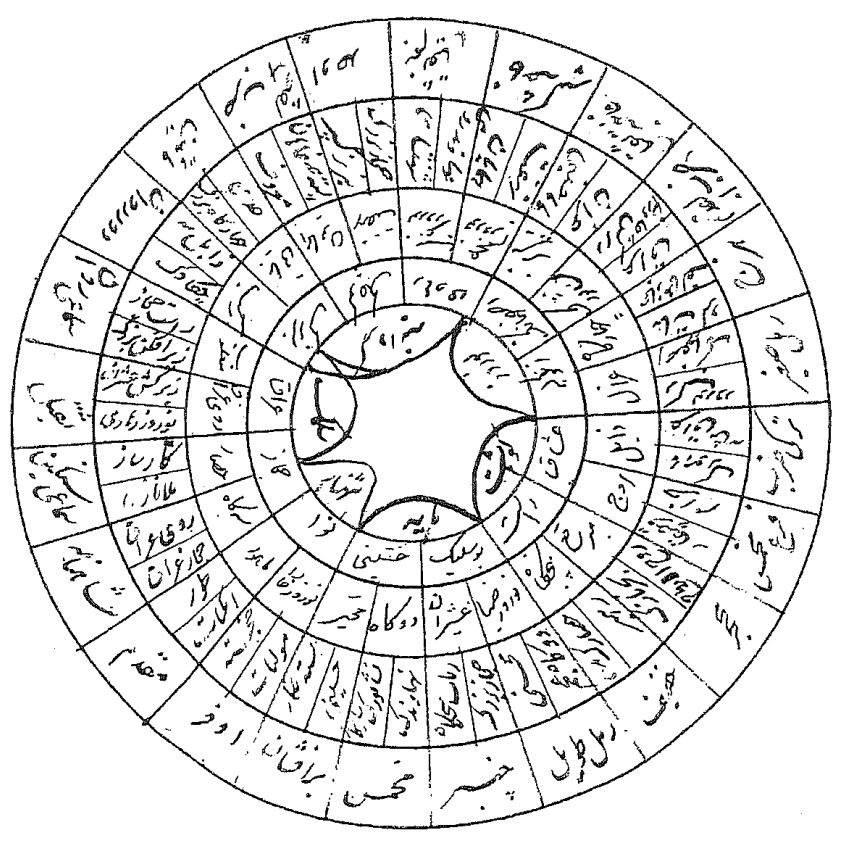

FIGURE 2. Charting of the twelve-maqam system in the Bahjat al-Rüh surrounded by the usul. Undated text held by the Bodleian Library Oxford University Ouseley 117, folio 23 recto

ities of the twelve-maqam system that would ultimately have a relationship with creating melody for the purpose of music-making in practice.

\section{MAKING MUSIC: THE TWELVE-MAQAM SYSTEM IN RHYTHM AND COMPOSITION}

In order to actually make music using the twelve-maqam system, a modal entity from the system had to be paired with rhythm and cast into a specific musical form in the course of composition. The twelve-maqam system had a parallel set of rhythmic patterns for percussion instruments, referred to as usul (usūl), typically discussed after descriptions of the twelve-maqam system. Descriptions of these rhythmic patterns changed over time, though they were often demonstrated using some imitation of the representation of 'aruz (' $\operatorname{aru} \dot{z}$ ): the system of poetic meters (buhūr) used as the basis of both Arabic and Persian poetry. While some writings substitute 'aruz for a distinct system of rhythmic conception, the two also appeared side by side with different specific representations of rhythm eventually replacing any reference to 'aruz altogether.

Like the maqam, avaz and sho'beh, and gusheh, the usul each had proper names to distinguish different usul from one another in language. The prolific musician and author 'abd al-Qader al-Maraghi writing in the fifteenth century 


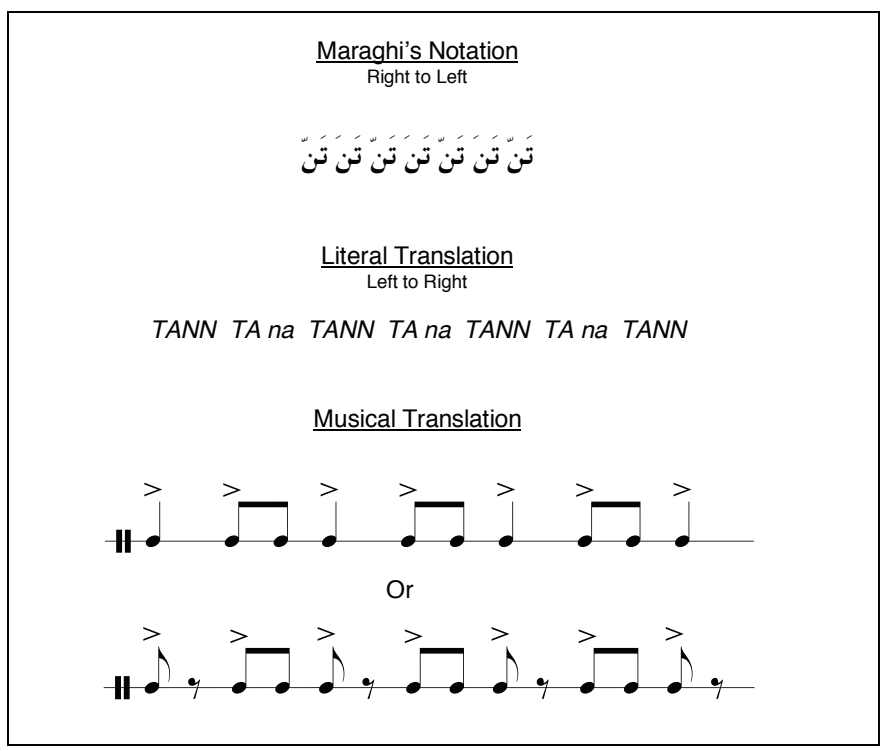

FIGURE 3. The Khafif Saqil rhythmic cycle according to Maraghi

thus described a series of rhythmic cycles (advār-i $\left.\bar{i} q \bar{a}^{e} \bar{a} t\right)$ common in his time using various distributions of vowels around the consonants te $ت$ and nun $ن$ provided varying amounts of description beyond this notation, which had been used in Graeco-Arabic writings centuries before. For example, he described a cycle named "light-heavy" (khafif $\underline{s}$ squil) as a cycle of fourteen beats while also indicating which beats where played and which were silent (see figure 3 ). ${ }^{7}$

The notion of usul embodied this concept of a metered pattern of rhythm serving as the organization of time underpinning melodies composed using maqam, avaz, or sho beh. While this basic premise was a consistent one for the actual creation of melody in the twelve-maqam system, the usul and description of usul varied over time. Thus, writing at the end of the seventeenth century in the Safavid court in Isfahan, the head of court musicians, Amir Khan Gorgi, notated some different usul, using syllables built around the consonants dal $د$ and kaf $ک$. Thus Amir Khan described an usul of his time named ramal as having two versions, one significantly longer than the other (see figure 4$){ }^{8}$

The place where both maqam and usul came together to make music was in composition. Indeed, while there was no tradition of notating compositions for preservation, the few written notations of music in the twelve-maqam tradition were theoretical demonstrations of composition, showing how to apply usul and maqam together to create a set melody within a set meter. ${ }^{9}$ Improvisation, by contrast, had no specifically formulated place in the system and there is no description of how one would improvise within the twelve-maqam system. Music-making was always the proper matching of elements of the twelve-maqam system with usul 


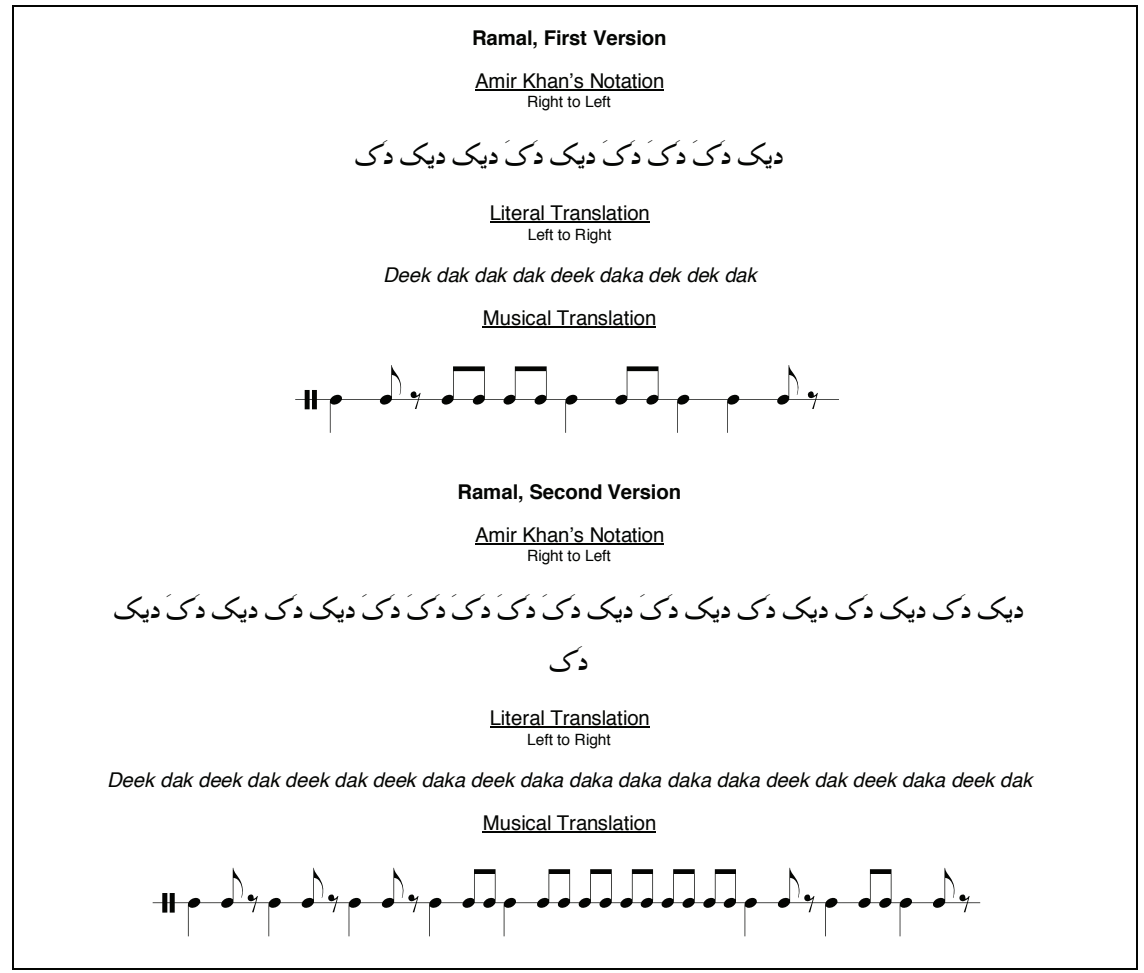

FIGURE 4. Two versions of the Ramal rhythmic cycle according to Amir Khan

within specific set compositional forms. These compositional forms were often the last aspect of music to be described in writings about the twelve-maqam system, even as the forms themselves changed over time.

Compositional forms could be defined by several factors, including their internal organization, whether they were instrumental or vocal, and which usul were typically used. The poetry genre and language being used also distinguished different song types from one another. Structures within compositions were typically stated without definition, though the terminology itself might offer insight into what defined different parts of a composition. The most commonly stated term for a distinct section of melodic development within a composition was khaneh (khäneh), which may or may not be further defined within the description of a particular form. In this way, Maraghi described the compositional form pishraw (pishraw) as an instrumental piece with anywhere from two to fifteen khaneh, or two to fifteen distinct melodic sections. He implied that different khaneh may have melodies built upon different maqam, avaz, and sho beh, while also stating that ramal was one of the typical usul used in the composition of a pishraw. Maraghi stated that if someone added poetry to a melody of a khaneh from a pishraw and performed that song with the original usul of the pishraw, this type of song would be called a hava'i (havāâ).10 
Conversely, he used the term qawl ( $q a w l$ ) to refer to any singing done in Arabic, whether set in musical meter without a specific poem in mind or sung with a known poem with reference to the poem's specific poetic meter. The preeminent suite organization described by Maraghi was the nawbat murattab, which was a suite of songs that began with a qawl, followed by a ghazal (ghazal): a song sung in Persian and organized according to the same rhythmic as the opening qawl. The ghazal would be followed by a taraneh, which was a song that could be sung in either Arabic or Persian, but it had to use poetry organized in quatrains (ruba'i) and use an usul that facilitated the phrasing of quatrains. The nawbat murattab ended with a song form called foru dasht (furu dasht), which Maraghi simply described as a song in Arabic. Unlike the more general term qawl, the foru dasht was a specific type of Arabic song that only appeared at the end of the nawbat murattab and served as a closing section of the entire suite.

Most compositional forms were songs that were partially defined by the language and poetry they used with implications for the rhythmic cycles they could accommodate. Even with rhythm being a primary consideration, they could still also have complex melodic organizations. Thus Maraghi described a song form sung in Persian called 'amal ('amal), which had its own specific progression of sections: first an introductory section he called motla' (motla'), then a middle section he referred to as sawt (sawt) or miyan khaneh (mīyān khāneh), and finally a concluding melodic section he referred to as both tashiyeh (tashīyeh) and baz gasht (bāz gasht). ${ }^{11}$

While there are variations in descriptions of compositional forms within the twelve-maqam system from the fifteenth and sixteenth centuries, their descriptions are relatively consistent until the seventeenth century. References to some compositional forms within the twelve-maqam system disappear in the seventeenth century, including the nawbat murattab. A generally defined pishraw instrumental form remained, while song forms were added and redefined. While Persian writings on the twelve-maqam before the seventeenth century alternated between Arabic and Persian terms for sections of compositions, treatises of the seventeenth-century Safavid Empire employed a fairly standardized Persian terminology. This included references to primary melodic sections (sar khāneh), the middle or secondary melodic section (mīyān khāneh), and final sections that could be alternately referred to as recapitulations or reprises (bar gasht), or codas (zayl). In addition to these defined melodic sections, Safavid song forms using the twelve-maqam system were also defined by whether or not they started with poetry (ash 'är) or "hits" (naqarāt). Sections of hits had no words, and the usul alone defined the music's rhythm without poetry. In sections of hits the voice sang on a system of vocables rather than poetry.12

The placement of sections of hits and sections of poetry in songs was key in defining Safavid compositional forms, even as sar khaneh, miyan khaneh, and bar gasht/zayl were also part of defining form. For instance, a previously general term for any musical composition, kar $(k \bar{a} r)$, became a Safavid term for a specific form that started with a section of hits, followed by poetry and then another section 
of hits. ${ }^{13}$ Yet a kar's actual form contained two sar khaneh, which were then followed by a miyan khaneh that had its own melodic development, which was then followed by a zayl or bar gasht. The term 'amal ('amal) came to denote the same structure of two sar khaneh, miyan khaneh and bar gasht, only it began starting with poetry rather than a section of hits. It appears that both sar khaneh usually began with either a section of hits or poetry in order to define a form as either kar or 'amal. What made the miyan khaneh section different was its completely different melodic development in comparison with the sar khaneh, and its ability to start with either a section of hits or poetry.

Safavid compositional forms presented somewhat different organizations and definitions from forms of the fifteenth century. It gave the form called 'amal a completely different conception, and the term qawl also came to denote a different form. By the seventeenth century, the qawl was no longer denoted an Arabic song, but rather a Persian song that followed the same structure as the kar and 'amal, but did not have the final bar gasht.

Indeed Arabic did not keep its standing as a common language for song after the sixteenth century. In the Safavid Empire, it was replaced by Turkish. Amir Khan described four distinct Turkish song genres, each defined by their use of different types of Turkish poetry. Indeed, though the Ottoman Empire is considered beyond the narrative of Iranian music history, Ottoman courts shared some features of compositional form with music in the Safavid Empire, including a mixture of Turkish and Persian songs, and the instrumental pishraw (peşrev). ${ }^{14}$

The diverse, changing usul and compositional forms that accompanied the twelve-maqam system demonstrate that it had a place in practice that was greatly concerned with both metered melody and set, replicable forms for music composition. Song forms were the most common types of compositional forms, with a variety of musical features defining the distinction between different types of songs. The use of poetry often determined the use of usul, but not always. Yet the dominance of song in the musical practices associated with the twelve-maqam system put much emphasis on the use of language. While Persian was the lingua franca of writing, it was not the sole language of music-making, or of life in the empire. The twelve-maqam system's polyglot song forms reflect the continuing polyglot nature of its primary context in and around various dynastic courts, where the religions, the rulers, and their administration used language other than Persian.

\section{MUSIC OF THE SHAH, SULTAN, AND SUFISM}

Though Safi al-Din wrote from the capital of the Abbasid Caliphate, the Abbasids had already lost much of their imperial dominance by the time he gained their patronage, a situation highlighted by Nishaburi's affiliation with the Ghaznavid court in former Caliphate lands farther east. Music's dependency on royal patronage (like poetry's and philosophy's) had a history that preceded any mention of twelve shadd, pardeh, or maqam. Court music had a basis in the practices of the 
Byzantine and Sasanian Empires, which various Caliphates often adopted as part of their own model of empire as they conquered Byzantine and Sasanian lands. At its height in the tenth century, the 'Abbasids and their constituent aristocracy in Baghdad patronized musicians from all over the growing Islamic world, with the Umayyad Caliphate based in Cordoba fostering a similarly polyglot culture of musical patronage under the umbrella of Islamic rule. Documentation indicates that Persian-speaking people from the former Sasanian Empire were well represented among the servants and entertainers at the Caliphal courts, and they continued to serve similar roles in the post-Caliphate dynastic administrations.

The gradual waning of the Caliphate initially put musicians in service to subsidiaries of the 'Abbasids, who in turn became primary dynastic authorities over smaller aspects of the Caliphate. For instance, al-Farabi had been patronized by the 'Abbasid Caliph al-Riadii (r. 934-940), to whom he dedicated his now famous work on music, Kitāb al-mūsìqā al-kabìr. Yet al-Riadi ultimately became bankrupt and powerless, and the philosopher and musical polymath moved on to a subsequently long tenure in Aleppo with the Hamdanian ruler Sayf al-Dawlah (r. 945-967). The rule of the Hamdan family had been appointed and overseen by the 'Abbasids, but the weakening of the 'Abbasids brought the Hamdanian rulers into their own independent ruling position over their administrative lands, which brought their own independent patronage of music.

The loosening of 'Abbasid control farther east allowed both 'Abbasid subsidiaries and other powers to come to the fore of dynastic rule. Ibn Sina lived most of his relatively short life in the eastern portion of former 'Abbasid territory under the patronage of three different small dynasties: the Samanids (819-999), the Buyids (934-1062), and the Ghaznavids (977-1186). Each of these kingdoms represented different factors influencing the end of 'Abbasid rule in Central Asia. As with the Hamdanian kingdom, the Samanids were a local family ruling as a subsidiary of the 'Abbasids. The Buyids were also indigenous to Central Asia, but 'Abbasid influence had become so weak they were able to overtake the Samanids despite having fewer ties to 'Abbasid rule. The Turkic Ghaznavids then invaded from farther east, one of the first Turkic dynasties to emerge out of invasions and more generalized migration from the east (see map 1). The dynastic landscape of ibn Sina's lifetime was a portrait of what it meant to live on the edge of empire. The empire's borders were porous and ever changing, even as direct dynastic control over large empires was limited.

The slow demise of the 'Abbasids and these specific developments on their easternmost borders formed the basis of a new phase for ruling Islamic dynasties, which would ultimately be dominated by dynastic rulers who were Mongol, Turkic, or some combination of both, with a geography of urban ruling centers in former Sasanian lands. This was the context of the twelve-maqam system's emergence. It came into full common parlance over a vast region where dynastic principalities were coming and going, even as centers of Islamic dynastic power in the region shifted east as Mongol and Turkic invaders moved West. 


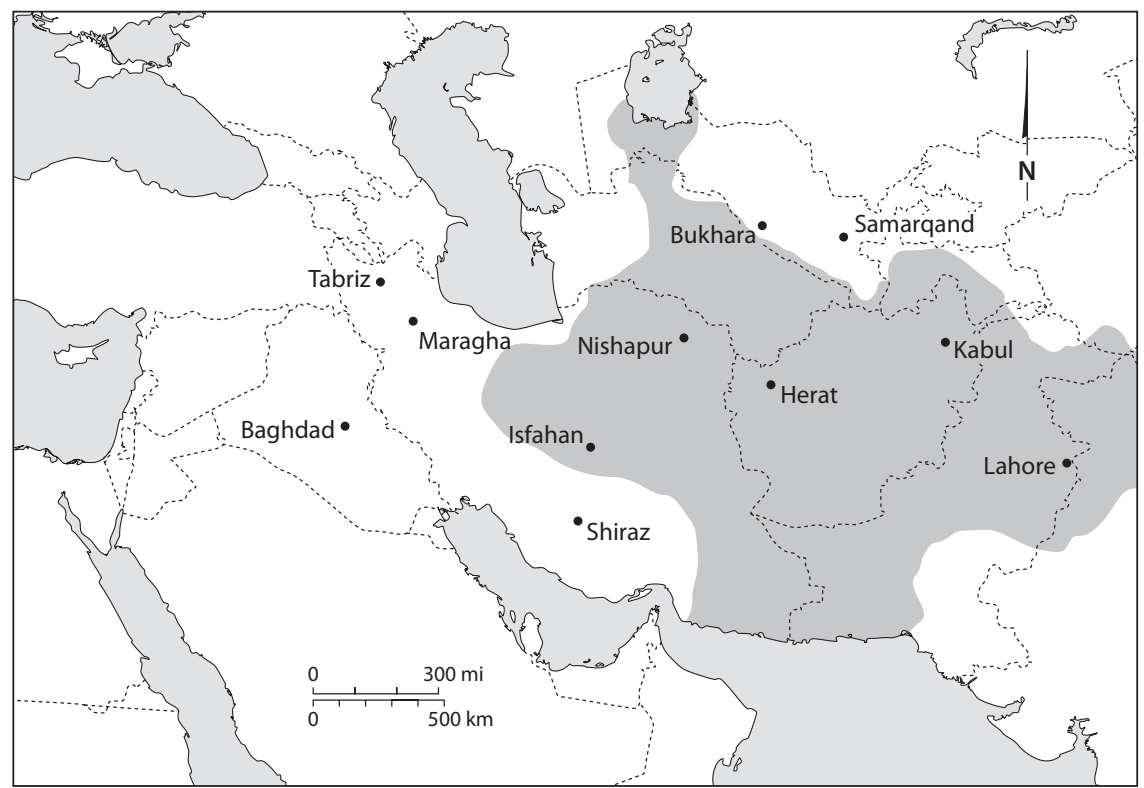

MAP 1. The Ghaznavid Empire at its largest

The new arrivals from East Asia built upon existing dynastic institutions, just as the 'Abbasids had. Yet the Mongol siege of Baghdad signaled a pivotal change. In a world where Islam came to define successful imperial expansion, the Mongol's full contravention of the Caliphate initially presented a seminal intervention in the cosmic order. Conversely, the nomadic invaders' ultimate adoption of Islam, and their appropriation of sedentary dynastic rule and indigenous signification of dynastic hierarchy, opened up a new cycle of cosmic history. With centers of dynastic power established on top of lands that had been part of both the Abbasid and the Sasanian cosmic order, Mongol-Turkic dynasts pulled from multiple indigenous dynastic legacies in order to establish and maintain their legitimacy. Their adoption of Persian as their lingua franca highlighted the layers of indigenous symbolism repurposed to support their rule. As an already established language of dynastic power from Sasanian times, the Persian language emerged in the wake of Mongol and Turkic rule as a lingua franca that had since transformed to embody both dynastic and Islamic power. Imbued with the sacred iconographs of Islam's written Arabic language and extensive Arabic vocabulary, Persian in the wake of the Caliphate embodied both a regional history of cosmic dynastic authority and the religious authority of Islam. For dynastic rulers with no attachment to the specific history of the Caliphate, this represented a strong balance of political and religious legitimization. Kingly epochs, whether about contemporary rulers or legends of rulers past, further legitimated their rule: all stories of kings, 
shahs, and sultans, whether pre-Islamic or contemporary, could legitimate the post-Caliphate dynastic order.

In this context, dynastic rule's relationship with Islam was parasitic. The Turkic and Mongol adoption of indigenous religion served to support their inherent right to rule, even as Islamic authorities could not keep their positions if not for the favor of the newly converted dynasts. Mysticism proved to be a valuable aspect of Islam for invading powers, as more non-Arabic speaking people converted and held political power over communities of Muslims who were not necessarily Arabs. Mysticism and syncretism made Islam more accessible to the converted, even as new dynasts provided support for intellectual Islamic thought. In current narratives of Iranian music history, the seemingly liberal approaches to Islam after the Mongol invasion foster a golden age of Persian culture, as music, literature, and art using the Persian language become expressions of aristocratic culture. Yet this context related to the power of Mongol and Turkic rulers, in addition to the indigenous value of the Persian language. Turkic rulers specifically would continue to dominate ruling West and Central Asia up until the twentieth century, and their ever-changing fortunes and political condition determined the continuity and geographic distribution of the twelve-maqam system.

Though Turkic rulers established some presence in Persian-speaking territory before the Mongols, Chingiz-Khan's extensive invasion of Central and West Asia brought Mongol rulers to the fore. From the twelfth to the sixteenth century, control over the region of the twelve-maqam system would move primarily between the control of Mongol and Turkic rulers. The initial Mongol rulers represented localized subsidiaries of Chingiz-Khan's larger empire, and thus carried the title of ilkhan. The first Ilkhanate moved into Khurasan in 1221, expanding toward Baghdad and into Anatolia (see map 2). While the original Ilkhanate ultimately ended around 1328, other smaller Mongol kingdoms that had emerged around and on top of the Ilkhanate ruled smaller areas from Khurasan to Antaolia until the cusp of the fifteenth century (see map 3).

After Safi al-Din and Nishaburi, some of the first Persian writings about the twelve-maqam system that address it in relation to the earlier Arabic writings of Safi al-Din occurred under Mongol patronage. Musicians themselves continued to move from court to court following court patronage as they had before, yet the growth of Islamic mysticism also opened up the possibility that people engaging in musical expression would travel to different regions following various Sufi sects and pilgrimage practices. In either case, music would still move with some frequency, with the underpinning of dynastic patronage serving as the primary support of the cosmopolitan music culture associated with the twelve-maqam system.

The writers that produced more technical descriptions of the twelve-maqam system after the Mongol invasion initially maintained Mongol court affiliations. Qutb al-Din Shirazi's (1236-1311) discussion of twelve pardeh in relation to Safi al-Din's adwar appeared in his larger encyclopedia of philosophy, Durrat al-tāj. 


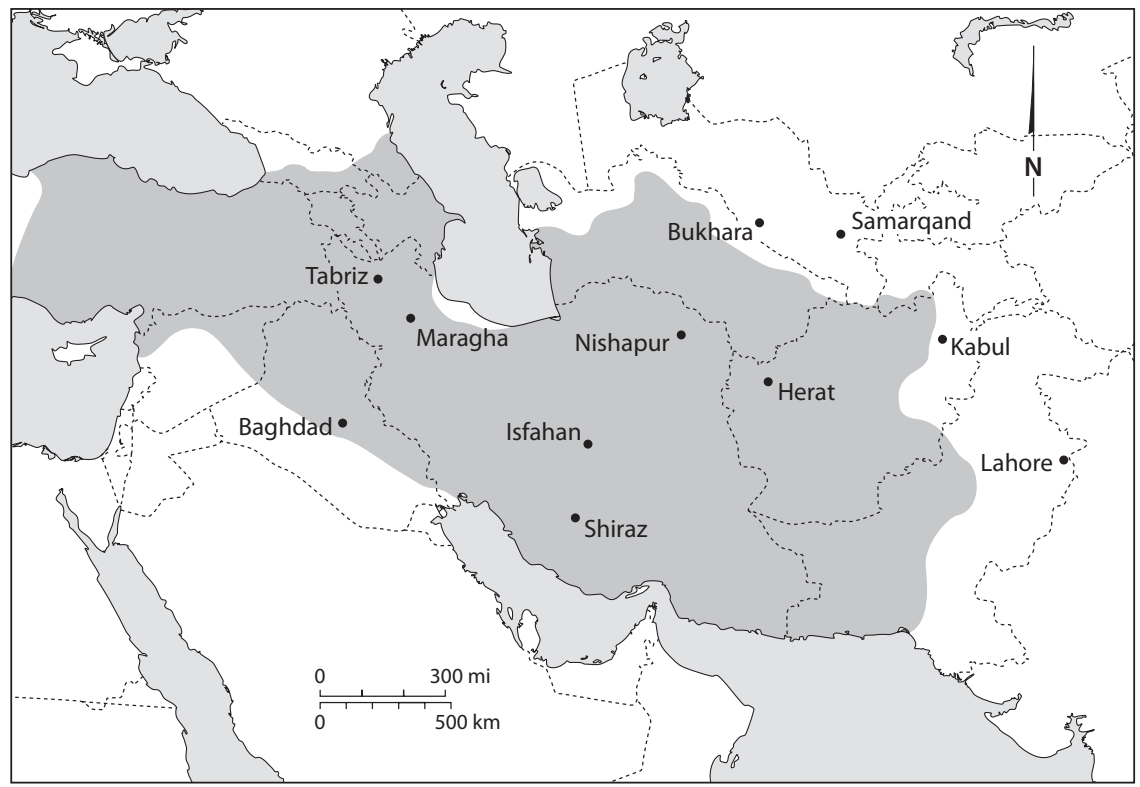

MAP 2. The Ilkhanate at its largest

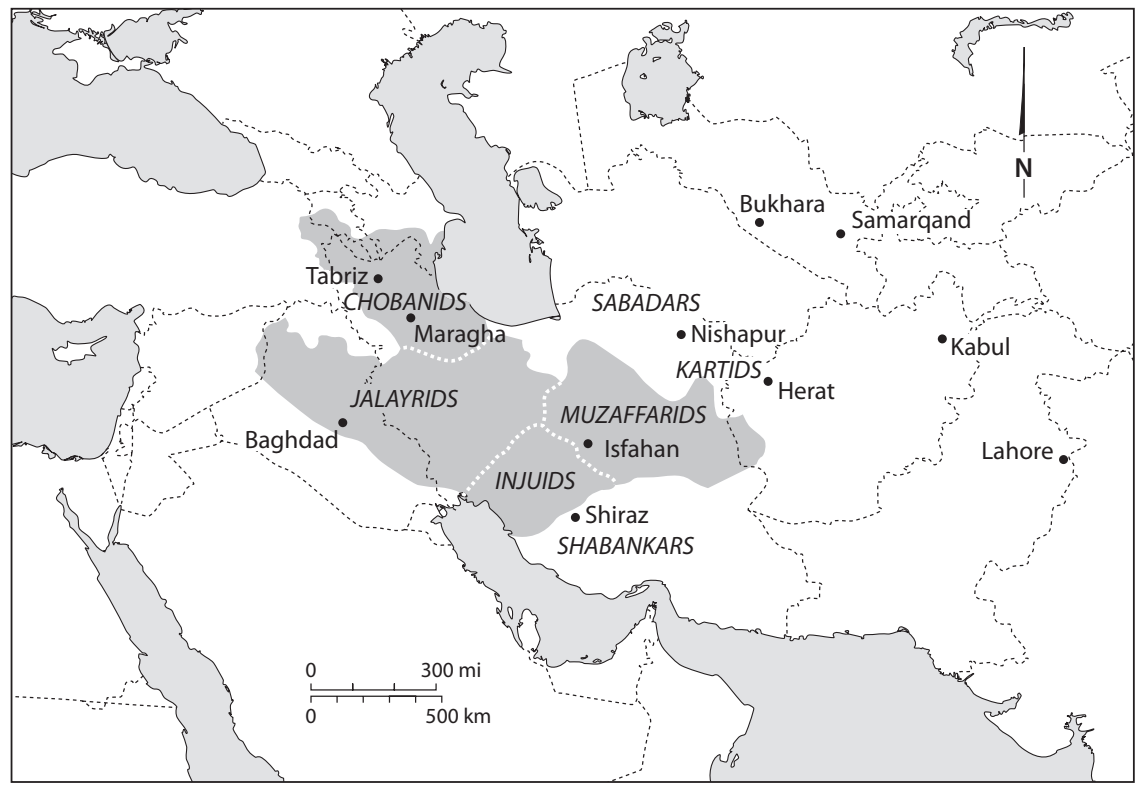

MAP 3. Division of the former Ilkhanate, c. 1345. Shaded areas show areas held by Mongol rulers: the Chobanids, Injuids, Jalayarids, and Muzaffarids 
As a doctor, philosopher, and mystic, this encyclopedia was just one of the major texts Qutb al-Din wrote while acting as a political liaison at various regional courts, most notably an official representative of the Ilkhan ruler Ahmad Nikudar (r. 1281-1284). A lesser-known philosopher, Shams al-Din Muhammad ibn Mahmud al-Amuli, also produced an encyclopedic work that included a section on music and twelve pardeh, the Nafä'is al-funün, under the patronage of another offshoot of the Ilkhanate, the Mongol Injuid Sultanate that controled land southwest of Isfahan (r. 1335-1357).

If the most educated of aristocratic society pondered music from the confines of the court, musical performers who primarily served as entertainers were subject to these confines as well. Perhaps the best-known prolific Persian court musician, 'abd al-Qader Maraghi, moved far and wide to serve both Mongol and Timurid courts. He was a servant under the first Ilkhanate, and then moved into the courts of the Mongol Jalayarid Dynasty when they overtook his initial patrons. Among the Jalayarids he was first patronized by Sultan Husayn I (r. 1374-1382) and then by Sultan Ahmad (r. 1383-1410). With the rise of Timur and the Timurid Empire, Maraghi moved to the Timurid courts to serve Timurid patrons and he died while in service to the Timurids around 1434. In his lifetime he lived and worked in disperate cities, including Baghdad, Shiraz, Samarqand, and Herat.

Maraghi's writings about the twelve-maqam system are dated from his time in Herat, though he would have worked on them much earlier. His most extensive music, titled Jami al-alhān, provided both commentary on Safi al-Din and Qutb al-Din and descriptions of practice from Maraghi's time. Unlike many of the writers before him, Maraghi did not appear to be a polymath or a philosopher. He specialized in music and was a highly valued court musician who who attained high standing in the courts he served. As an educated and literate musician, he read and wrote in both Arabic and Persian. His movement between many different cities and courts demonstrates the amount of movement a highly valued, educated musician could have in one lifetime, as different dynasts came to power and sought musicians for different courts and different seats of power in different capital cities.

The rise of the Timurid Empire initially supplanted many smaller Mongol kingdoms in West and Central Asia with one larger empire controlled by Timur himself and by members of his distinct Turko-Mongol clan. Timur spent the end of the fourteenth century taking control of smaller Mongol territories that had replaced the larger IlKhanate, adding these lands to others he had conquered farther east (see map 4). Under the guise of reestablishing the administrative divisions that had made up the single great empire of Chingiz Khan, Timur maintained Persian as lingua franca in the former Mongol Ilkhanate lands and kept many courtly customs of these Mongol predecessors. Despite his interest in reuniting the Mongol Empire, however, the Timurid Empire struggled to remain united after Timur's death in 1405. Turkmen specifically maintained active campaigns to take lands from Timurid rulers (see map 5). 


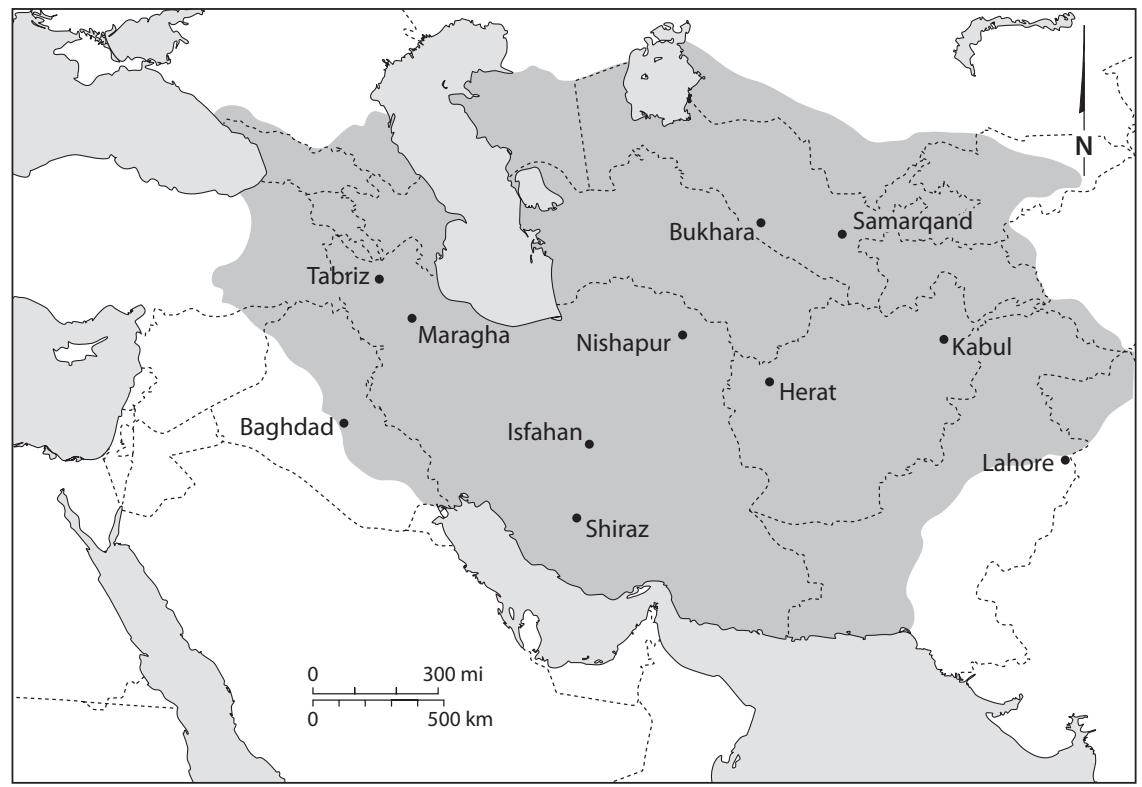

MAP 4 . The Timurid Empire at its largest

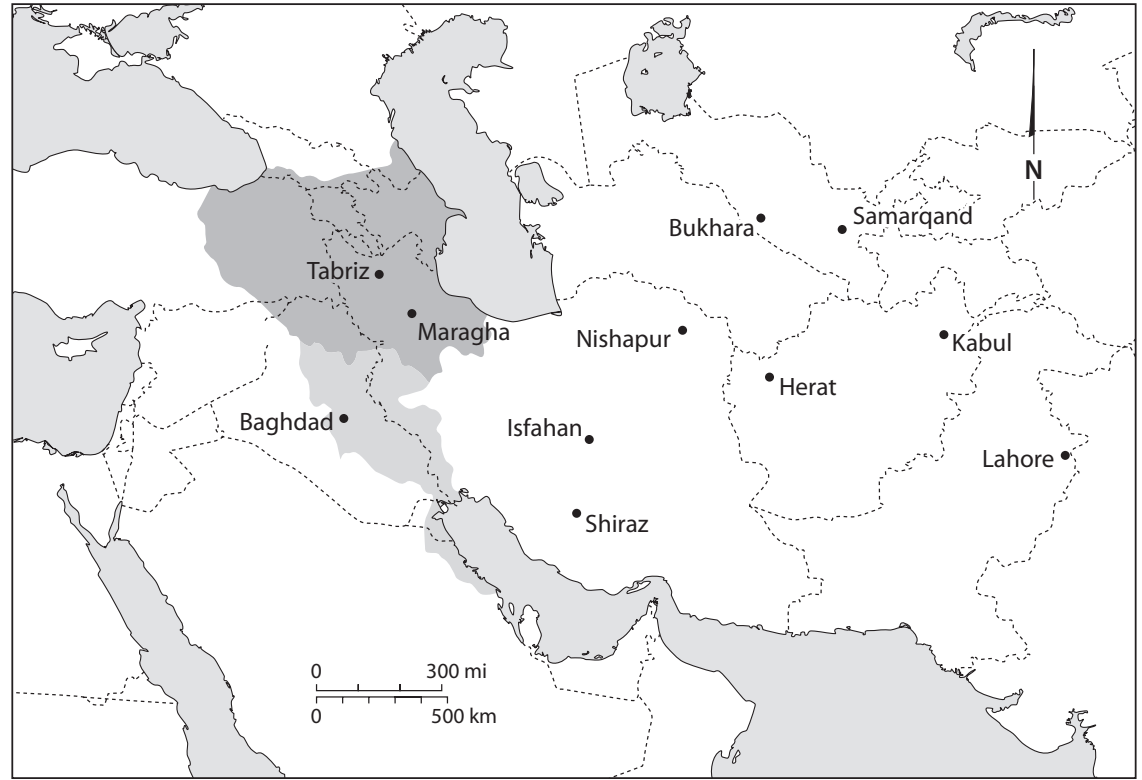

MAP 5. The empire of the Qara Qoyunlu Turkomans. Darker shading shows the core areas they held, while the lighter shading shows areas briefly held. 
Discussions of the twelve-maqam system written somewhat later than the lifetime of Maraghi highlight the ongoing movement of musicians between Timurid courts, the courts of their subsidiaries, and dynastic challengers, and some movement related to Sufi pilgramages. For instance, the poet Bana'i produced an extensive treatise on music and the twelve-maqam system in the vein of Maraghi dated 1482. In his lifetime, Bana'i served both in the courts of Timurid rulers and in courts of their subsidiaries, the White Sheep Turkmen (Aq Qoyūnlü). In his court service he moved between Herat, Baghdad, Tabriz, and Qandahar to serve different dynasts at different times. ${ }^{15}$ The poet and Sufi scholar Nur 'abd al-Rahman Jami (1414-1492) was also highly valued at court. In his poetry and mystical writings, there is a short treatise on music in line with Qutb al-Din and Maraghi. Jami studied in Samarqand and also served both Timurid court in Herat and the White Sheep court in Tabriz, while also traveling extensively for Sufi pilgramage. ${ }^{16}$

The rise of the twelve-maqam system in tandem with Mongol-Turkic Empires marked a significant musical change at the moment of significant political change, yet the political change mantained the tradition of music patronage among the dynastic aristocracy, which had previously been modeled under the Caliphate and empires that the Caliphate had displaced. Musicians, musical thought, and the twelve-maqam system itself moved according to the changing fortunes of different dynastic rulers. While these moves could take music and musician across long distances to very different geographical spaces, the cosmopolitian setting of the court provided a similar cultural context for the twelve-maqam system across both space and time.

\section{THE TWELVE-MAQAM SYSTEM IN THE AGE OF GUNPOWDER}

In current narratives of Iranian music, the Timurid era represents the pinnacle of Persian music's golden age, while the end of their rule and the rise of the Safavid Dynasty in the sixteenth century represent a period of musical decline in Persian music's evolutionary development. But the dynastic model of governance did not disappear with the Safavids, nor did the twelve-maqam system. The rise of the Safavids in the sixteenth century coincided with a new era of Muslim empire, where new technologies allowed for more centralized dynastic power throughout West, Central, and South Asia (see map 6). Dubbed the era of gunpowder empires, the Safavids, Ottomans, and Mughals all developed various means of more centralized administration around this time, even as they continued to battle one another in the continued imperial struggle for ever more land and resources. Islam remained the religion of all three empires, with the Safavids recasting themselves as divine figures within their own constructions of Shía Islam.

This new era of Mulsim empire still had court cultures built out of previously established norms of courtly life. Timurid musicians initially moved on 


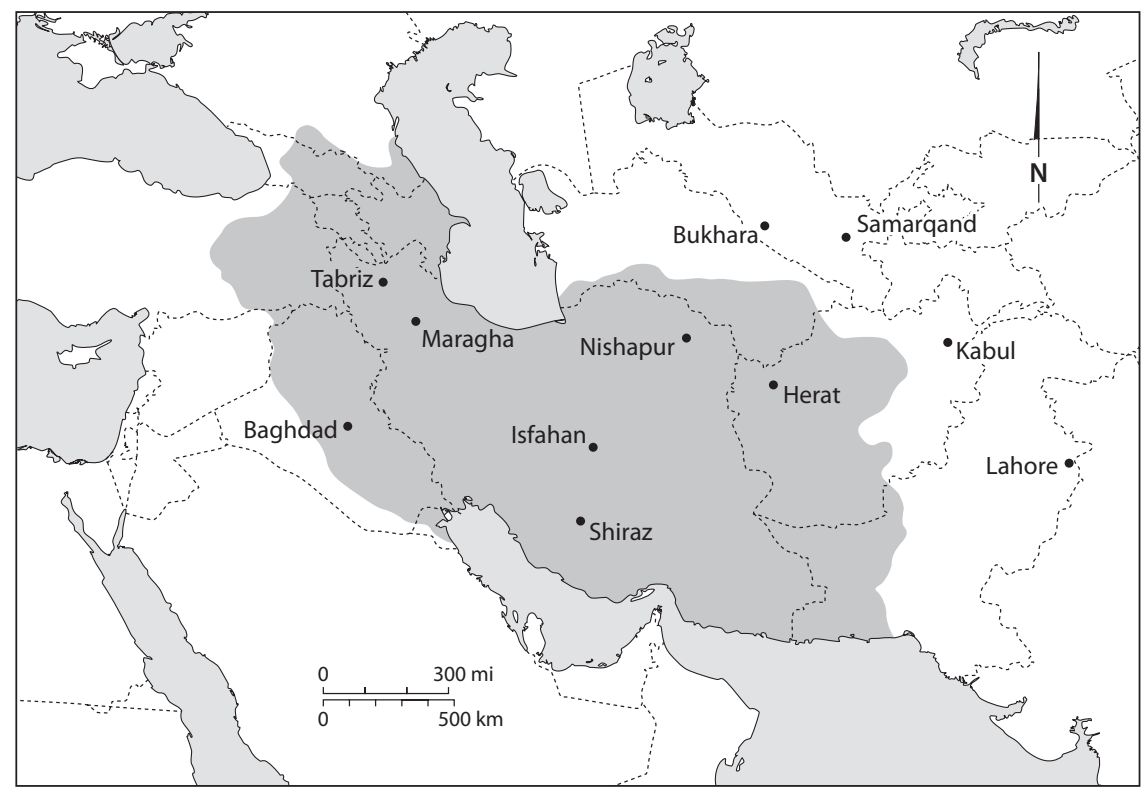

MAP 6. The Safavid Empire at its largest under Shah 'Abbas I (r. c. 1599-1629)

to serve the courts of all three of these dynasties and the twelve-maqam system went with them to all three empires. But the twelve-maqam system and its specific conceptual basis did not remain centrally dominant to music-making in all three empires. The music of Ottoman courts moved toward an open system of modes and the long-form musical structure fasil now synonymous with Ottoman music. ${ }^{17}$ In the Mughal courts writings about music acknowledged and explained the twelve-maqam system's structure as an alternative presentation of the indigienous modal system of South Asia. It was thus only in the Safavid Empire that the twelve-maqam system remained the most dominant concept of music's proper derivation and the relevanncy of the twelve-maqam system ultimately depended on Safavid patronage. This meant that the fall of the Safavids in the early eighteenth century and the subsequent chaos that followed seriously compromised the twelve-maqam system's standing. Ultimately the fall of the Safavids opened up space for additional conceptions of music's organization to gain relevance before consistent music patronage returned under the Qajar dynasty.

The Safavids had ambigous ethnic origins and initially premised their power on the idea they were descendents of the Prophet Muhammad. They came from a syncretic Islamic tradition that combined various aspects of Sufism and Shi'ism, and the first Safavid shah, Shah Isma'il, declared himself to be both the rightful ruling dynast and a unique manifestation of divinity on Earth. The Safavid Empire 
thus developed around a distinct conception of Shi'a Islam that cultivated a unique orthodoxy concerning the merging of divine authority with dynastic authority. This centralization of the two key nexuses of power in the premodern Islamic world had a corollary in the Ottoman Empire, which claimed authority to rule based in part on the idea they descended from the Caliphate.

The movement of Timurid musicians into the Ottoman court resulted in the son of 'abd al-Qader al-Maraghi serving the Ottomans in their first Anatolian capital, modern-day Bursa. He wrote a Persian treatise about the twelve-maqam system, dedicated to the Ottoman Sultan Mehmet II. ${ }^{18}$ Some previous writings about the twelve-maqam system were also reproduced in Ottoman territory, yet none of these specific writings about the system from the past was reproduced in Safavid territory. Beyond initial Timurid transplants, the Ottomans and Safavids directly exchanged musicians in military bargains, and the greater military success of the Ottomans suggests that musicians tended to move from the Safavid Empire to the Ottoman Empire when such exchanges took place. ${ }^{19}$

While the military rivalry between the Ottomans and Safavids created particular circumstances for musicians moving between these two empires, Timurid musicians also joined the Mughal courts, and later some musicians serving Safavid rulers also served patrons of the Mughal aristocracy. Like those of the Ottomans, Mughal writings about the twelve-maqam system include reproductions of some older writing about the twelve-maqam system, including writings of Qutb al-Din and a copy of Hassan Kashani's Persian text from the fourteenth century titled Kanz al-tuhaf, which also described the twelve-maqam system in the context of Safi al-Din's adwar. ${ }^{20}$

The more widespread documenation of musicians moving from Timurid to Mughal territory is the twelve-maqam system itself, which appears in Persian writings from Mughal lands beginning in the seventeenth century and continuing throughout the eighteenth century. Unlike the Ottomans, who eventually developed an Arabic script for Ottoman Turkish and made it their official court language while moving toward an open modal system, the Mughals kept Persian as their court language into the nineteenth century and kept writing about the twelve-maqam system.

Persian writings about music from Mughal territory were not always reproductions of older writings, and original writings describing the twelve-maqam system from South Asia often placed it alongside South Asia's own rag/ragini system. A description of the twelve-maqam system is thus included next to the rag/ ragini system in the encylopedic work Tuhfat al-hind, composed around 1674 by the Mughal nobleman Mirza Khan ibn Fahr al-Din, in the court of the Mughal ruler Aurangzeb Alamgir (r. 1658-1707), for the ruler's son, Muhammad A'zam (1653-1707). A writer named Mazhar Muzaffar also authored a text that described the twelve-maqam system side by side with the rag/ragini system dedicated to the Mughal ruler Shah 'Alam II (1720-1806). ${ }^{21}$ 
The description of the maqam in these texts and others included the gusheh as a fundamental aspect of the system, indicating a similar understanding of the system to that in Safavid lands. This was in part because musicians from other regions continued to move to Mughal courts after the fall of the Timurids, including musicians from Safavid courts. For instance, one author of a section of text about the twelve-maqam system that referenced the gusheh structure was named Nizam al-Din Ahmad Gilan. He can be connected to the Safavid courts of Shah 'Abbas (1577-1628) and Shah Safi (1629-1642), and then to the court of the Mughal ruler 'abd Allah Qutb Shah (1611-1672).

While the movement of musicians continued to be controlled by the fortunes of empire, changes in administration also affected who participated in music-making and the twelve-maqam system. The Safavids pulled their military and administrative support from different populations of polyglot peoples than their Timurid predecessors. Their military support came from their Turkic Qizilbash followers, and they also appointed peoples of the Caucases to positions in their court administration. Thus, one of the last heads of court musicians at the Safavid court, Amir Khan Gorji, wrote a Persian tract about the twelve-maqam system and composed songs in Persian, but his name indicates he was actually Georgian. Additionally, Safavid songs could be set in Persian or Turkish.

Thus it was in the Safavid Empire of the sixteenth and seventeenth centuries that the twelve-maqam system remained central to the conception of music, even as there were amendments to previously established notions of music's structure and changes in the political players and polyglot makeup of courtly life. The modern perception of music's decline under the Safavids relates to several factors, including the apparent loss of collective musical memory and sophistication. Safavid writings about music do not display interest in the detailed considerations of music so important to Farmer's Systematic School, nor do they appear to maintain or even remember anything specific about Safi al-Din's adwar or its extrapolations like those of Qutb al-Din and Maraghi. The most tangible aspects of music's essence, such as sound and consonant intervals, lose their significance in writings from Safavid lands.

Another factor is the extent to which the centralization of empire meant that the Safavids did directly administrate music in ways unthinkable before their rise to power. Different Safavid rulers intervened to regulate or otherwise control court music, military music, and performative practices with musical content, such as shahnameh recitation and particular Shía ceremonies. Though court musicians were always subject to the whims and preferences of their courtly patrons, the Safavids' greater tendency to exert direct control over music suggests that musicians had less agency in their empire.

Yet another factor was the greater ability of the Ottomans and Mughals to support more extensive music patronage, as their courts maintained more continuity of such patronage throughout the eighteenth and the nineteeth centuries. The 


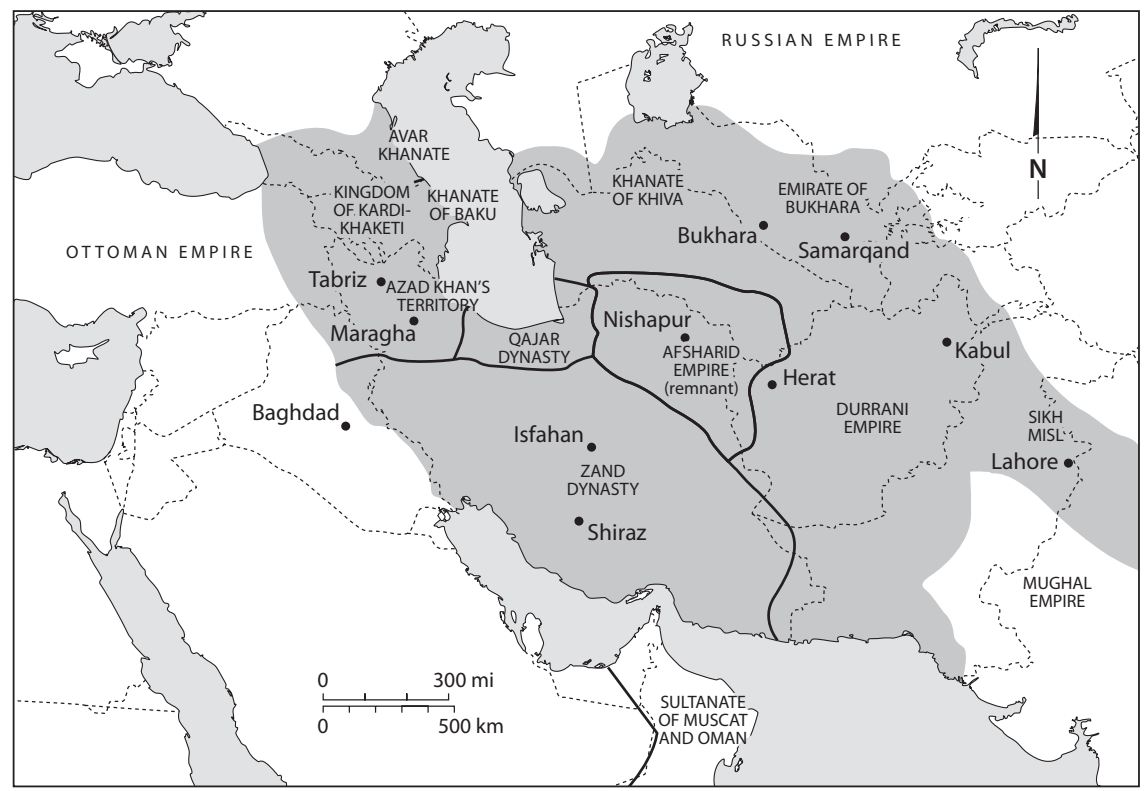

MAP 7. The Afsharids Empire at its largest and after its fall. The majority of lands initially accrued by the Afsharids (shaded) quickly became divided between various regional rulers, with the Zands controlling the largest portion of their former lands, and the Qajars maintaining a small seat of power from which they would eventually build their larger empire.

connection between Safavid music culture and that of its neighbors highlights the Safavid empire's smaller size, shorter tenure, and particularly devastating demise. While the Safavids were always trying to grow their empire and worked to expand as a matter of survival, they ultimately were not able to maintain control of most of the additional territory they gained. Some specific political and economic weaknesses of the Safavids as well as difficult confrontations with the Tsardom of Russia left Safavid rulers weak by the end of the seventeenth century. This allowed for a particularly brutal invasion by Afghan forces in 1722, which began a long period of political instability.

In this sense, the circumstances of Safavid's reign did create the beginning of the end of the twelve-maqam system. The political weakness of the Safavids and the particular circumstances of their fall changed the course of music history. While music patronage continued in Ottoman and Mughal territories straight through the eighteenth century, music patronage faltered in former Safavid lands along with dynastic rule as a whole. Brief apperances of large kingdoms like that of Nader Shah Afshar (r. 1736-1747) appear to have resulted in some music patronage, but the patronage was highly limited and short lived, as only Nader Shah and the Zands held on to significant amongs of land and resources, and then for rather short periods of time (see map 7 ). ${ }^{22}$ 
The history of the twelve-maqam system shows two distinct periods of its existence, followed by a rather sudden fading out of relevancy in the eighteenth century. In its era of dominance both the conception of pitch organization and the procedures for creating music were stable. The logic for establishing pitch modalities was conceved in terms of derivation, and music-making was largely an act of systematic composition in light of usul, language, and compositional forms. Changes and differences in aspects of this system's organization and performance demonstrate the active reality of music connected with dynastic courts. Musicians had to move and the twelve-maqam system had to adapt to changing dynastic contexts. Even during periods of relative stability in the twelve-maqam system's conception and practice, the lives of musicians could be quite unstable. Yet the basic parameters of the system prevailed from the cusp of the Mongol invasion in the thirteenth century until the ultimate decline of the dynastic model of governance beginning in the eighteenth century.

The abrupt fading out of the twelve-maqam system's relevance mirrored the abrupt fading out of dynastic models of governance that had supported it. While the fall of the Safavids fostered a uniquly chaotic situation for dynastic governance during the eighteenth century, the Ottomans and Mughals were also beginning to face new challenges to dynastic rule that would eventually render this model of governance mute. By the time dynastic governance obtained a stronger footing in former Safavid lands at the cusp of the nineteenth century, the entire model of dynastic governance was ending throughout the Middle East and South Asia: neither the twelve-maqam system nor the dynastic model of governance would survive the nineteenth century.

It was the circumstances of Islamic empire in the shadow of the Caliphate that formed the context of the twelve-maqam system, which stood as the optimum representation of all musical thought and practice until the eighteenth century, when both the twelve-maqam system and the dynastic model of governance quickly lost relevance. Throughout its tenure, the twelve-maqam system did not belong to one langauage group or an ethnolinguistic culture seperable from court life. Instead, it depended on the universal applicability of both dynastic heirarchy and Islam. It depended on sacred languages in polyglot contexts, and such cosmopolitian contexts were part of the structure of premodern empires in the Middle East and Central Asia. This cosmopolitan reality of dynastic life required distinct approaches to musical thought and expression and the twelve-maqam system represented both the specific requirements of this culture and the unique contingencies of its history. 